\title{
OBSERVATIONS ON THE PERMEABILITY PROPERTIES OF THE EGG MEMBRANES OF THE MARSUPIAL, TRICHOSURUS VULPECULA
}

\author{
R. L. HUGHES AND C. D. SHOREY \\ School of Zoology, University of New South Wales, N.S.W. 2033, and \\ Electron Microscope Unit, University of Sydney, Australia
}

(Received 13th December 1971)

\begin{abstract}
Summary. The permeability properties of the shell membrane, mucoid coat, zona pellucida and vitelline membrane of thirteen Trichosurus vulpecula eggs were investigated by incubating them in a mixture of the animal's own blood plasma and one of the following substances: vital toluidine blue (mol. wt. 306); horse radish peroxidase (mol. wt. 40,000); ferritin (mol. wt. 460,000). The degree of penetration of these tracers was assessed either with the light microscope or electron microscope or both.

Both toluidine blue and peroxidase penetrated the shell, the mucoid coat and the zona pellucida to enter the vitellus within $5 \mathrm{~min}$. In eggs with fully formed shell membranes and mucoid coats, ferritin particles penetrated the superficial portions of the shell in low concentrations. There were fewer particles in the deeper portions of the shell and, in the mucoid coat, they were extremely rare or absent. In eggs either lacking a shell or with a thin newly formed shell, ferritin infiltrated the zona pellucida. It was concluded that the pore size of the shell was such that some filtration of ferritin was occurring. Because of the penetration of substances with such a large molecular weight as ferritin and peroxidase, it was considered that neither the shell, the mucoid coat nor the zona pellucida was significantly involved in regulating the passage of embryonic nutrients or wastes.
\end{abstract}

\section{INTRODUCTION}

During the last 5 years, data have been accumulated on the reproductive cycles of some 400 female brush-tailed possums, Trichosurus vulpecula (Kerr). Ovulation is spontaneous in Trichosurus and occurs most frequently on about the 2nd day after oestrus. The single newly ovulated egg consists of a relatively yolk-free vitellus of about $229 \mu \mathrm{m}$ in diameter. As in other mammals, the vitellus is invested by a zona pellucida. Apart from the relatively large size of the vitellus, the egg of Trichosurus resembles that of the common laboratory and domestic eutherian mammals.

A tertiary egg membrane in the form of a strongly acidic mucoprotein coat 
(Pl. 1, Fig. 1) of some 50 to $80 \mu \mathrm{m}$ in thickness is deposited around the egg of Trichosurus during its passage through the ampulla and isthmus regions of the Fallopian tube. A similar mucoid coat is universally present on the eggs of all marsupial species so far studied. A mucoid coat also occurs on the eggs of a few eutherian mammals, is well known for the rabbit and the hare, and has also been reported for the horse and the dog (for a review see Blandau, 1961, p. 815). Although the eggs of most eutherian species lack a mucoid coat, it is likely that the epithelium of the Fallopian tube of virtually all eutherian mammals possesses specialized mucoprotein-secreting cells.

In Trichosurus, the lower portion of the Fallopian tube merges imperceptibly with the uterus, and the epithelium of this so-called intramural region contains tubular glands opening into its lumen. These strongly resemble the tubular endometrial glands of the uterus proper. Here, a thin keratinous shell (Pl. 1, Fig. 1) usually of less than $1 \mu \mathrm{m}$ in thickness is deposited around the laminated mucoprotein coat (mucoid coat). The shell continues to thicken after the egg reaches the uterus and may attain a maximum thickness of 7 to $10 \mu \mathrm{m}$ in the early unilaminar blastocyst stage or, in the case of the unfertilized eggs, after a few days' residence in the uterus. The mucoid coat maintains its original thickness of from 50 to $80 \mu \mathrm{m}$.

The mucoid coat disappears with the expansion of the blastocyst and the shell thins but, according to Sharman (1961), the shell membrane of Trichosurus persists for almost the entire gestation period of 17.5 days.

The pattern of events just described for the mucoid coat and shell of Trichosurus is essentially similar for at least six other marsupial species: the koala, Phascolarctos cinereus (Caldwell, 1887); the spotted native cat, Dasyurus viverrinus (= Dasyurus quoll) (Hill, 1910); the American opossum, Didelphis virginiana (Hartman, 1916; McCrady, 1938); the quokka, Setonix brachyurus (Sharman, 1961); the rat kangaroo, Bettongia cuniculus (Kerr, 1935); the potoroo, Potorous tridactylus (Kerr, 1935).

The primary purpose of this investigation was to determine whether the variations in the thickness or in the chemical composition of the tertiary coats might be causally linked with the regulation of the transport of embryonic nutrients or waste products. Incidental observations were also made on the zona pellucida and vitelline membrane.

\section{MATERIALS AND METHODS}

Experimental animals and recovery of eggs

A total of twelve possums, Trichosurus vulpecula, were captured between 13th March and 6th June in suburban domestic gardens around Sydney. A vaginal smear was taken from each animal on the day of capture and in the case of ten suckling females, young were also removed from the pouch. The vaginal smears were obtained and processed by a method previously described by Hughes (1962). The smears were subsequently interpreted with a view to determining oestrus, according to a table set out by Pilton \& Sharman (1962). Vaginal smears were taken from all animals on a daily basis commencing on or before the 7 th day after capture. 
The females with pouch young returned to oestrus between the 7 th and 13th day after removal of the pouch young. All the animals were killed 1 to 4 days after oestrus (usually on the 3rd day) and the single egg was flushed from

Table 1. Site of recovery, developmental stage and dimensions of the eggs of Trichosurus

\begin{tabular}{|c|c|c|c|c|c|c|}
\hline $\begin{array}{c}\text { Animal } \\
\text { no. }\end{array}$ & $\begin{array}{l}\text { Site of } \\
\text { recovery } \\
\text { of egg }\end{array}$ & $\begin{array}{c}\text { Stage of development of } \\
\text { egg }\end{array}$ & $\begin{array}{c}\text { Vitellus } \\
\text { diameter } \\
(\mu m)\end{array}$ & $\begin{array}{c}\text { Zona } \\
\text { thickness } \\
(\mu \mathrm{m})\end{array}$ & $\begin{array}{l}\text { Mucoid } \\
\text { coat } \\
\text { thickness } \\
(\mu \mathrm{m})\end{array}$ & $\begin{array}{c}\text { Shell } \\
\text { membrane } \\
\text { thickness } \\
(\mu \mathrm{m})\end{array}$ \\
\hline $\begin{array}{l}1 \\
2\end{array}$ & $\begin{array}{l}\text { Fallopian tube } \\
\text { Uterus }\end{array}$ & $\begin{array}{l}\text { Unfertilized } \\
\text { Approx. } 30 \text { cells with } \\
\text { small cavity }\end{array}$ & $\begin{array}{c}245 \\
221 \times 276\end{array}$ & $\begin{array}{c}3 \cdot 9 \\
\text { Not distinct }\end{array}$ & $\begin{array}{c}79 \\
39 \text { to } 79\end{array}$ & $\begin{array}{c}\text { Absent } \\
6.7\end{array}$ \\
\hline $\begin{array}{l}3 \\
4 \\
5\end{array}$ & $\begin{array}{l}\text { Fallopian tube } \\
\text { Uterus } \\
\text { Uterus }\end{array}$ & $\begin{array}{l}\text { Unfertilized, } \\
\text { fragmenting } \\
\text { Unfertilized } \\
\text { Unfertilized, }\end{array}$ & $\begin{array}{l}236 \cdot 5 \\
193 \cdot 1\end{array}$ & $\begin{array}{c}\text { Not recorded } \\
3 \cdot 2\end{array}$ & $\begin{array}{l}47 \cdot 3 \\
78 \cdot 8\end{array}$ & $\begin{array}{r}6.3 \\
<1.0\end{array}$ \\
\hline $\begin{array}{l}6 \\
7 \\
8 \\
9\end{array}$ & $\begin{array}{l}\text { Uterus } \\
\text { Uterus } \\
\text { Uterus } \\
\text { Uterus }\end{array}$ & $\begin{array}{l}\text { fragmenting } \\
\text { Unfertilized } \\
\text { Unfertilized } \\
\text { Unfertilized } \\
\text { Unfertilized, }\end{array}$ & $\begin{array}{l}256 \\
219 \cdot 9 \\
197 \\
221\end{array}$ & $\begin{array}{l}\text { Not distinct } \\
\text { Not distinct } \\
\text { Not seen } \\
\text { Not seen }\end{array}$ & $\begin{array}{c}15 \cdot 8 \\
39 \text { to } 79 \\
39 \cdot 4 \\
39 \text { to } 79\end{array}$ & $\begin{array}{r}3.9 \\
3.9 \\
<1.0 \\
2.8\end{array}$ \\
\hline $\begin{array}{l}10 \\
11\end{array}$ & $\begin{array}{l}\text { Uterus } \\
\text { Fallopian tube }\end{array}$ & $\begin{array}{l}\text { fragmenting } \\
\text { Unfertilized } \\
\text { Unfertilized, }\end{array}$ & $\begin{array}{l}236 \\
197\end{array}$ & $\begin{array}{l}\text { Not seen } \\
\text { Not seen }\end{array}$ & $\begin{array}{c}39 \text { to } 79 \\
78.8\end{array}$ & $\begin{array}{l}3 \cdot 9 \\
3 \cdot 6\end{array}$ \\
\hline $\begin{array}{c}12 \\
5 *\end{array}$ & $\begin{array}{l}\text { Fallopian tube } \\
\text { Uterus }\end{array}$ & $\begin{array}{l}\text { fragmenting } \\
\text { Unfertilized } \\
\text { Unfertilized, }\end{array}$ & $\begin{array}{l}236 \cdot 5 \\
197\end{array}$ & $\begin{array}{l}\text { Not recorded } \\
\text { Not distinct }\end{array}$ & $\begin{array}{l}39 \cdot 4 \\
72 \cdot 9\end{array}$ & $\begin{array}{c}3 \cdot 2 \\
\text { Absent }\end{array}$ \\
\hline & & fragmenting & 256 & Not recorded & $15 \cdot 8$ & 3.9 \\
\hline
\end{tabular}

* Two eggs were recovered from the uterus of the same animal.

Table 2. Characteristics and concentrations of tracers incubated with eggs of Trichosurus

\begin{tabular}{c|l|c|c|c}
\hline $\begin{array}{c}\text { Animal } \\
\text { no. }\end{array}$ & Type of tracer & $\begin{array}{c}\text { Molecular } \\
\text { weight of } \\
\text { tracer }\end{array}$ & $\begin{array}{c}\text { Concentration } \\
\text { of tracer } \\
\text { (mg/ml plasma })\end{array}$ & $\begin{array}{c}\text { Duration of } \\
\text { incubation } \\
(\text { min })\end{array}$ \\
\hline 1 & Toluidine blue & 306 & $0 \cdot 2$ & 5 \\
2 & Toluidine blue & 306 & $0 \cdot 2$ & 5 \\
3 & Peroxidase & 40,000 & $0 \cdot 5$ & 30 \\
4 & Peroxidase & 40,000 & $0 \cdot 5$ & 30 \\
5 & Peroxidase & 40,000 & $0 \cdot 5$ & 5 \\
6 & Peroxidase control & Nil & Nil & 30 \\
7 & Ferritin & 460,000 & $10 \cdot 0$ & 30 \\
8 & Ferritin & 460,000 & $10 \cdot 0$ & 5 \\
9 & Ferritin & 460,000 & $5 \cdot 0$ & 30 \\
10 & Ferritin & 460,000 & $0 \cdot 5$ & 30 \\
11 & Ferritin & 460,000 & $0 \cdot 5$ & 30 \\
12 & Ferritin & 460,000 & $0 \cdot 5$ & 5 \\
5 & Ferritin control & Nil & Nil & 30 \\
\hline
\end{tabular}

either the Fallopian tube or uterus with 2 to $5 \mathrm{ml}$ of the animal's own blood plasma in a hypodermic syringe fitted with a blunt 26-gauge needle. The diameter of the vitellus of the egg together with the thickness of the zona pellucida, mucoid coat and shell were measured using a Leitz 12.5 screw 
micrometer eyepiece and a $\times 10$ objective. These data, together with the site of recovery and developmental stage of the eggs, are shown in Table 1.

\section{Plan of experiment}

The permeability properties of the egg membranes were determined by assessing the degree of penetration of tracer substances. Eggs were incubated in $1 \mathrm{ml}$ of the animal's own blood plasma containing a known concentration of tracer. Details of the type of tracer used, together with their concentration and incubation times, are summarized in Table 2.

\section{Experimental techniques}

Blood plasma was obtained from each animal by cannulating the iliac artery and collecting $20 \mathrm{ml}$ blood into heparinized centrifuge tubes in an ice bath. The blood was then centrifuged at $4^{\circ} \mathrm{C}$ at $3000 \mathrm{rev} / \mathrm{min}$ for at least 15 $\min$. The blood plasma was then pipetted into a separate centrifuge tube.

Toluidine blue (mol. wt. 306) was used as a vital stain with $1 \mathrm{mg}$ of toluidine blue being dissolved in $5 \mathrm{ml}$ blood plasma. Two grades of toluidine blue were used. In the case of animal No. 1, the toluidine blue was manufactured by the Allied Chemical \& Dye Corporation, New York, and was certified by the Biological Stain Commission. Gurr's vital toluidine blue was used for animal No. 2. Within 3 to $5 \mathrm{~min}$ of death, the Fallopian tube and uterus were removed from the body cavity and individually flushed with blood plasma containing the dissolved toluidine blue. The recovered egg was then incubated in the flushing solution at room temperature and the progress of the penetration of the stain followed initially with a dissecting microscope. When the period of incubation was completed, the egg was washed and preserved in a $5 \%$ formaldehyde solution. The degree of penetration of the toluidine blue was then reassessed microscopically at a magnification of $\times 100$.

Horse-radish peroxidase (mol.wt. 40,000), manufactured by Sigma Chemicals, St Louis, was used as a molecular tracer. Eggs were flushed from the Fallopian tube or uterus using the animal's own blood plasma and then transferred to a solution of $0.5 \mathrm{mg}$ horse-radish peroxidase in $1 \mathrm{ml}$ blood plasma and incubated at $37^{\circ}$ G. According to Cortan \& Karnovsky (1968), a concentration of $0.5 \mathrm{mg}$ peroxidase $/ \mathrm{ml}$ is the minimum dilution to give a reasonably strong cytochemical reaction that can be detected by electron microscopy. The egg from animal No. 6 was used as a peroxidase control and incubated in blood plasma only. The duration of incubation for individual eggs is shown in Table 2. After incubation, eggs were pipetted into a fixative consisting of Karnovsky's fluid diluted with equal parts of cacodylate buffer at $\mathrm{pH} 7 \cdot 4$. Eggs were fixed at room temperature for 3 to $5 \mathrm{hr}$ and then washed in cacodylate buffer at $4^{\circ} \mathrm{C}$ for $12 \mathrm{hr}$. The extent of penetration of the peroxidase was determined by visualizing, with both the light and electron microscope, the location of a brown reaction product that develops after treating the fixed peroxidase-incubated eggs for $10 \mathrm{~min}$ in a saturated solution of 3-3' diamino-benzidine hydrochloride. The method of Cortan \& Karnovsky (1968) was used to prepare the 3-3' diamino-benzidine hydrochloride. The eggs were then washed in four changes of distilled water before being examined at $\times 100$ by light microscopy. After 
post-fixing in a $1 \%$ solution of osmium tetroxide made up in Palade's buffer for $3 \mathrm{hr}$, the eggs were washed in Palade's buffer for $10 \mathrm{~min}$ and transferred to a saturated solution of uranyl acetate in Palade's buffer for 15 min. Finally, they were transferred to $70 \%$ alcohol in preparation for embedding for electron microscopy.

Ferritin (mol. wt. 460,000, diameter of particles $110 \AA$ ) $2 \times$ crystalline, cadmium-free and derived from horse spleen was obtained from Nutritional Biochemicals Corporation, Ohio, U.S.A. This substance was also used as a molecular tracer. The eggs were flushed from the Fallopian tube or uterus in the animal's own blood plasma and then incubated at $37^{\circ} \mathrm{C}$ in a mixture of ferritin and plasma at the concentrations and for the times shown in Table 2. The eggs were then fixed in Karnovsky's fluid diluted with equal parts of cacodylate buffer at $\mathrm{pH} 7.4$ for 3 to $5 \mathrm{hr}$ at room temperature. Washing was then carried out in cacodylate buffer at $4^{\circ} \mathrm{C}$ for $12 \mathrm{hr}$, followed by three brief changes of water. After post-fixation for $2 \mathrm{hr}$ in a $1 \%$ solution of osmium tetroxide made up in Palade's buffer, the eggs were rinsed in Palade's buffer and transferred to a saturated solution of uranyl acetate in Palade's buffer for $15 \mathrm{~min}$. Finally, they were transferred to $70 \%$ ethyl alcohol for embedding for electron microscopy.

\section{Electron microscopy}

After dehydration in ascending grades of alcohol, the eggs were transferred to xylene for $2 \mathrm{~min}$ and infiltrated in Araldite at room temperature for $48 \mathrm{hr}$ before being embedded in fresh araldite and polymerized at $60^{\circ} \mathrm{C}$. Sections were cut at a thickness of less than $600 \AA$ and mounted on hexagonal grids covered with a nitrocellulose-carbon supporting film. The unstained sections were examined in a Philips 300 electron microscope fitted with a goniometer stage.

\section{RESULTS}

Permeability of egg membranes to toluidine blue

Observations of a shell-less tubal egg with the light microscope showed that toluidine blue penetrated the vitellus within $5 \mathrm{~min}$ (Table 3). However, in animal No. 2, the toluidine blue penetrated only to the zona pellucida at the end of $5 \mathrm{~min}$ and was later found in the blastomeres of the fertilized egg after a total incubation time of $30 \mathrm{~min}$ (Table 3 ).

\section{Permeability of egg membranes to peroxidase}

Details of the permeability properties of the four eggs (from animals Nos 3 to 6) used in these experiments are shown in Table 3. All four eggs had a shell and mucoid coat surrounding the zona pellucida. The penetration of the peroxidase in the unsectioned eggs could be determined to a limited extent with the light microscope by observing the presence of a brown reaction product that formed after the eggs were incubated with peroxidase and treated after fixation with a saturated solution of 3-3' diamino-benzidine hydrochloride. The eggs used for light microscope observations were subsequently processed 
for electron microscopy and the precise distribution of the reaction product was determined. Its presence was manifest as a marked increase in the electron density of cellular organelles associated with a fine precipitate of densely packed particles. This can be clearly seen by comparing the electron micrographs (Pl. 1, Fig. 1 and Pl. 2, Fig. 2) of a peroxidase-treated egg with that of the untreated control (Pl. 2, Fig. 3). It can be seen from Table 3 that all egg membranes were readily permeable to peroxidase. In the three test eggs, peroxidase penetrated the shell, the mucoid coat, the zona pellucida and vitelline membrane to enter the vitellus within either 5 or $30 \mathrm{~min}$ of incubation. No reaction product developed in a control egg where peroxidase was omitted from the experimental procedure.

Table 3. Extent of penetration of Trichosurus eggs by tracers

\begin{tabular}{|c|c|c|c|c|c|}
\hline \multirow{2}{*}{$\begin{array}{l}\text { Animal } \\
\text { no. }\end{array}$} & \multirow{2}{*}{ Type of tracer } & \multicolumn{4}{|c|}{ Extent of penetration of tracer } \\
\hline & & Shell & $\begin{array}{c}\text { Mucoid } \\
\text { coat }\end{array}$ & $\begin{array}{c}\text { Zona } \\
\text { pellucida }\end{array}$ & Vitellus \\
\hline $\begin{array}{l}1 \\
2\end{array}$ & $\begin{array}{l}\text { Toluidine blue } \\
\text { Toluidine blue }\end{array}$ & + & + & $\stackrel{+}{+}$ & $\begin{array}{c}+ \\
+ \text { after } \\
30 \mathrm{~min}\end{array}$ \\
\hline $\begin{array}{l}3 \\
4 \\
5 \\
6\end{array}$ & $\begin{array}{l}\text { Peroxidase } \\
\text { Peroxidase } \\
\text { Peroxidase } \\
\text { Peroxidase control }\end{array}$ & $\begin{array}{l}+ \\
+ \\
+\end{array}$ & $\begin{array}{l}+ \\
+ \\
+\end{array}$ & $\begin{array}{l}+ \\
+ \\
+\end{array}$ & $\begin{array}{l}+ \\
+ \\
+\end{array}$ \\
\hline $\begin{array}{r}7 \\
8 \\
9 \\
10 \\
11 \\
12 \\
5\end{array}$ & $\begin{array}{l}\text { Ferritin } \\
\text { Ferritin } \\
\text { Ferritin } \\
\text { Ferritin } \\
\text { Ferritin } \\
\text { Ferritin } \\
\text { Ferritin control }\end{array}$ & $\begin{array}{c}+ \\
+ \\
+ \\
+ \\
\text { Limited } \\
-\end{array}$ & $\begin{array}{c}+ \\
\text { Limited } \\
\text { Limited } \\
\text { Limited } \\
- \\
++ \\
-\end{array}$ & $\begin{array}{l}+ \\
- \\
- \\
+ \\
-+\end{array}$ & $\begin{array}{l}- \\
= \\
- \\
\overline{-}\end{array}$ \\
\hline
\end{tabular}

\section{Permeability of egg membranes to ferritin}

The detection of the degree of penetration of the ferritin particles was exclusively confined to examination of sections of the middle third of the eggs in the electron microscope. The results are summarized in Table 3. The eggs of animals Nos 7 to 12 were used to investigate the permeability of egg membranes to ferritin and a second egg from animal No. 5 was used as a ferritin control. A similar pattern of permeability was exhibited by eggs from animals Nos 8, 9, 10 and 11. In these eggs, the small discrete particles of ferritin had penetrated the superficial layers of the shell in low concentrations with the deeper layers of the shell containing fewer scattered particles. The ferritin particles were extremely rare or, in one case (egg from animal No. 11), absent from the mucoid coat. In no instance in this group were ferritin particles seen

\section{EXPLANATION OF PLATE 1}

Fig. 1. Low power electron micrograph of the unfertilized egg from possum No. 3 showing shell membrane (SH), mucoid coat $(\mathrm{MC})$, zona pellucida $(\mathrm{ZP})$ and vitellus (VIT). The high electron density of the organelles in the vitellus is due to the penetration of peroxidase. 


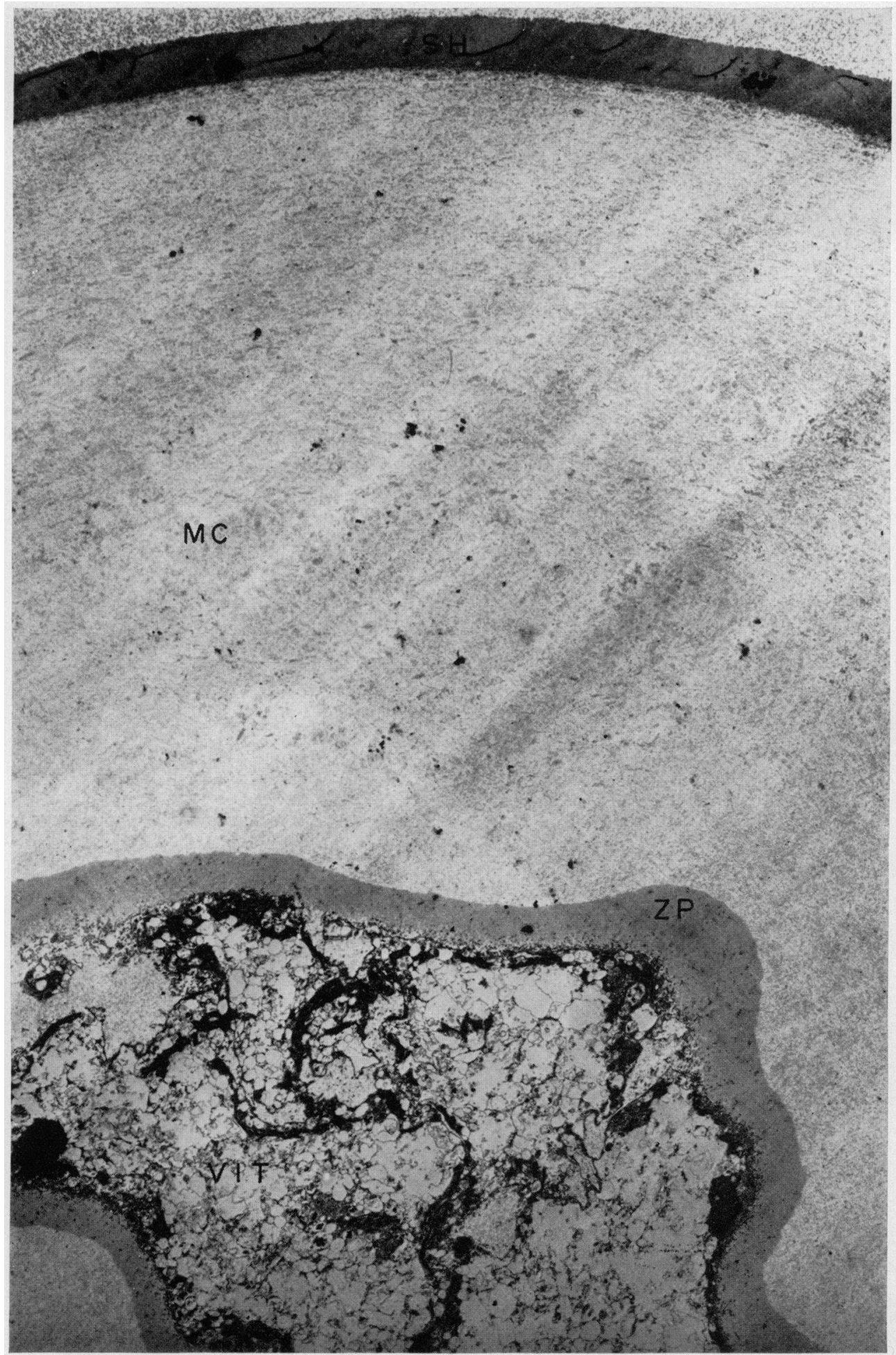

(Facing p. 30) 
P. ITE?

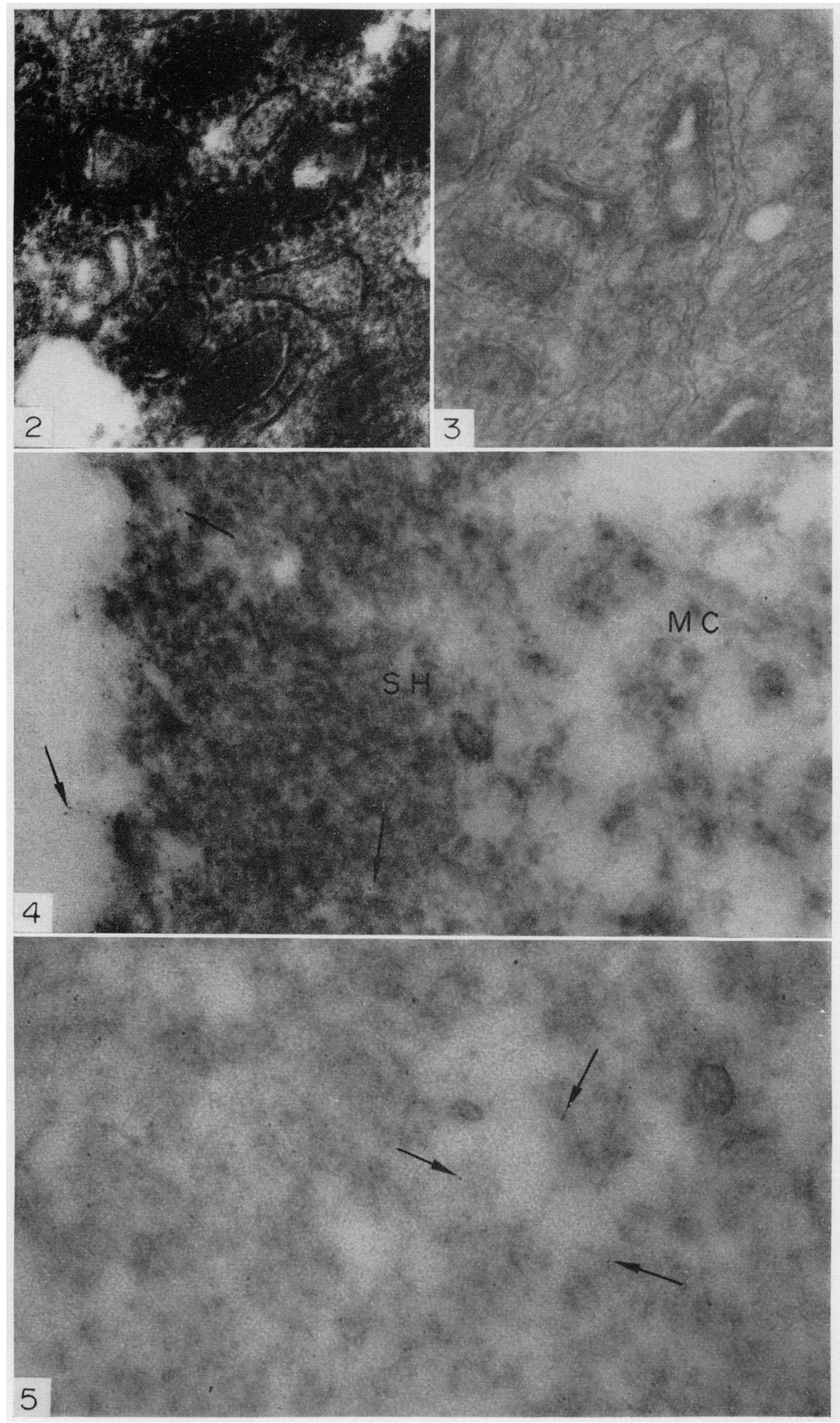


in either the zona pellucida or the vitellus. Table I shows that all these eggs possessed a well-developed shell and mucoid coat, while it can be seen from Table 2 that these eggs were those that were incubated either at a high concentration of ferritin ( $10 \mathrm{mg} / \mathrm{ml}$ plasma) for a short time $(5 \mathrm{~min})$ or at a moderate $(5.0 \mathrm{mg} / \mathrm{ml}$ plasma) or low $(0.5 \mathrm{mg} / \mathrm{ml}$ plasma) concentration of ferritin for a long time $(30 \mathrm{~min})$. It can be seen from Table 3 that in two other instances (eggs of animals No. 7 and No. 12) the ferritin particles penetrated into the zona pellucida. In the case of the egg from animal No. 7, Table 1 and Pl. 2, Fig. 4 show that the shell was extremely thin and appeared to have been recently formed, while Table 2 shows that a high concentration of ferritin was used $(10 \mathrm{mg} / \mathrm{ml}$ plasma) for a prolonged period $(30 \mathrm{~min})$. In the shell-less egg of animal No. 12, extensive penetration of ferritin particles had occurred despite the low concentration of ferritin $(0.5 \mathrm{mg} / \mathrm{ml}$ plasma) and the short incubation time of 5 min (Pl. 2, Fig. 5).

It should be noted in Table 3 that, in no instance, did penetration of the vitellus by ferritin particles occur and that no particles were evident in any region of the egg in the ferritin control.

\section{DISCUSSION}

It is evident from this study that the pore size of the egg shell is such that some filtration of ferritin is occurring, while peroxidase readily penetrates the shell. This would suggest that the shell would not be significantly involved in regulating the passage of embryonic nutrients or wastes. A similar conclusion may be deduced for the mucoid coat which offers even less of a barrier to the tracer substances than does the shell. Likewise, the zona pellucida is permeable to both ferritin and peroxidase.

It should be pointed out that the egg shell, the mucoid coat and the zona pellucida are in the form of non-living extracellular membranous coats and so would be expected to degenerate more slowly after ovulation than would the vitelline membrane, which is the cell membrane of the egg. It is considered that the permeability properties of the shell, the mucoid coat and, to a lesser extent, the zona pellucida demonstrated in this study approximate to their typical function in nature. However, the penetration of the vitellus by peroxidase and possibly also by toluidine blue is considered to reflect degenerative changes

\section{EXPLANATION OF PLATE 2}

FIG. 2: High power electron micrograph of portion of the vitellus of egg from possum No. 3. The high electron density is due to the penetration of peroxidase.

Fig. 3. High power electron micrograph of portion of the vitellus of egg from possum No. 6. This is the peroxidase control. Note the lack of electron density in the vitellus.

Fig. 4. Electron micrograph of the shell membrane (SH) and superficial portion of the mucoid coat (MC) of the unfertilized egg from possum No. 7. The micrograph shows ferritin particles (arrowed) accumulated mainly in the superficial part of the shell membrane. Other micrographs showed ferritin particles in the mucoid coat and the zona pellucida.

FIG. 5. Electron micrograph of portion of the mucoid coat of the unfertilized egg from possum No. 12 showing numerous ferritin particles (arrowed). Other micrographs showed extensive penetration of the zona pellucida by ferritin. This egg was recovered from the Fallopian tube and lacked a shell membrane. 
in the vitelline membrane associated with the deterioration of the unfertilized egg. The delayed penetration of the blastomeres by toluidine blue in the only fertilized egg investigated would seem to support this view.

Austin \& Lovelock (1958), in a study of the permeability of rabbit, rat and hamster egg membranes, reported that the cumulus oophorus and zona pellucida of rat, hamster and rabbit eggs, and the mucoid coat of rabbit eggs were permeable to solutions of toluidine blue digitonin (mol. wt. 1200) and alcian blue (mol. wt. 1200). The mucoid coat of rabbit eggs and the zona pellucida of rat and rabbit eggs were apparently not permeable to solutions of heparin (mol. wt. 16,000). From considerations of molecular weight alone, it was concluded that the vitellus of the tubal egg or eggs in culture of the species concerned should be directly accessible to all known essential food constituents, including vitamins, to the great majority of pharmacologically active compounds and toxins, and to all natural steroid hormones. These conclusions would seem to be equally applicable to the egg of Trichosurus. Austin \& Lovelock (1958) also concluded that the egg membranes of the species that they studied were evidently impermeable to most enzymes, antigens, antibodies and protein-containing hormones. Our observations suggest, however, that the vitellus of the eggs of Trichosurus would have virtually unrestricted access to almost all enzymes and antibodies as well as to all of the protein-containing hormones.

\section{ACKNOWLEDGMENTS}

We wish to thank the following members of the staff of The Electron Microscope Unit, University of Sydney, for their help: Miss Robin Arnold for technical assistance with the electron microscopy and Mr D. E. Tichborne and Miss Dianne Higginbothan for photography.

\section{REFERENCES}

Austin, G. R. \& Lovelock, J. E. (1958) Permeability of rabbit, rat and hamster egg membranes. Expl Cell Res. 15, 260.

BLANDAu, R. J. (1961) Biology of eggs and implantation. In: Sex and Internal Secretions, 3rd edn, Vol. II, p. 797. Ed. W. C. Young. Williams \& Wilkins, Baltimore.

Caldwell, W. H. (1887) The embryology of Monotremata and Marsupialia. Part I. Phil. Trans. $R$. Soc., Ser. B, 178, 463.

Cortan, R. S. \& Karnovsky, M. J. (1968) Ultrastructural studies on the permeability of the mesothelium to horseradish peroxidase. F. Cell Biol. 37, 123.

Hartman, C. G. (1916) Studies in the development of the opossum Didelphys virginiana L. I. History of the early cleavage. II. Formation of the blastocyst. F. Morph. 27, 1.

HiLl, J. P. (1910) Contributions to the embryology of the Marsupialia. 4. The early development of the Marsupialia, with special reference to the native cat (Dasyurus viverrinus). Q. Fl microsc. Sci. $56,1$.

Hughes, R. L. (1962) Reproduction in the macropod marsupial Potorous tridactylus (Kerr). Aust. $\mathcal{F}$. Zool. 10, 193.

KERR, T. (1935) Notes on the development of the germ layers in diprotodont marsupials. $Q \cdot f l$ microsc. Sci. 77, 305.

MCCrady, E. (1938) The embryology of the opossum. Am. anat. Mem. No. 16.

Pilton, P. E. \& Sharman, G. B. (1962) Reproduction in the marsupial Trichosurus vulpecula. 7. Endocr. $25,119$.

Sharman, G. B. (1961) The embryonic membranes and placentation in five genera of diprotodont marsupials. Proc. zool. Soc. Lond. 137, 197. 